\title{
Making do on not much: High Energy Striving, Femininity and Friendship in Broad City
}

\author{
By Akane Kanai \& Amy Dobson
}

\begin{abstract}
In the years following the 2008 global financial crisis ("GFC"), feminist media scholarship has drawn attention to the gendered calls in Western media culture to remake subjectivity in line with imperatives of thrift required in conditions of austerity. In the shared symbolic environments that "gender the recession" (Negra \& Tasker, 2014), media ranging from news, reality television, and film have placed further, intensified demands on women's domestic, affective, paid an $\mathrm{d}$ unpaid labour, requiring attitudinal orientations combining future-oriented enthusiasm, positivity, entrepreneurialism, a continued faith in (budget-conscious) consumption and investment in the home and the family. This article considers the US comedy Broad City as an articulation of how young women are critically grappling with such shifts in gendered social relations and labour markets in the cosmopolitan setting of New York City. We suggest, in the depiction of the central female friendship between Abbi Abrams (Abbi Jacobson) and Ilana Wexler (Ilana Glazer) in Broad City, the show foregrounds the necessity of young women's "high energy striving" but produces an alternative configuration of the normative relation between femininity and labour. In the show, contra the "retreatism" Negra and Tasker document idealising women's work in the home as a means of combatting an austere future, the thrifty fun, care, support, and love Abbi and Ilana strive to create together spills across public spaces, spanning the streets of the city, outdoors in parks and on stoops. Abbi and Ilana are continually depicted labouring in some way, though such labour does not generally result in financial or career-based reward, but rather, produces psychic and emotional sustenance for the women's friendship and a means of affectively investing in each other. Thus, in Broad City's acknowledgement of the high energy striving required to survive, the show critically questions the relation of such feminine striving to the promise of career, financial success, and the idealised direction of such striving towards the domestic and hetero-patriarchal family. Instead, the show emphasises the material importance of such striving in relation to the bonds of women's friendship in conditions of material and social hardship, suggesting a different orientation to women's work and its place in recessional culture.
\end{abstract}

Keywords: Young women, affect, recessional culture, neoliberalism, labour.

Akane Kanai \& Amy Dobson: "Making do on not much: High Energy Striving, Femininity and Friendship in Broad City", Culture Unbound, Volume 11, issue 3-4, 2019: 517-533. Published by Linköping University Electronic Press: http://www. cultureunbound.ep.liu.se 


\section{Introduction}

In the first episode of the US TV comedy Broad City, "What a wonderful world" (S1, Ep 1), we meet best friends, Ilana Wexler and Abbi Abrams, played by the showrunners Ilana Glazer and Abbi Jacobson. Ilana and Abbi are two Jewish women in their 30s surviving and attempting to thrive in New York City, epitomising generational and gendered shifts in the social contract. While Ilana and Abbi have benefited from increased access to education they also experience the failed promises of "passionate work" (McRobbie 2016), career fulfilment and financial stability for the middle classes. Both graduates of New York University ("NYU"), the two women are, several years later, yet to capitalise on their educational investments. In the show's early seasons, the free-spirited, eccentric Ilana is employed at a call centre named "Deals! Deals! Deals!", where her controversial social media promotional tactics end up getting her fired. Abbi, who aspires to be either an artist or a gym trainer, works as a cleaner at Soulstice Gym, a high end establishment where the seemingly glamorous work of training beautiful, sometimes celebrity, bodies is contrasted with Abbi's actual tasks that involve removing bodily excretions from its shiny surfaces. In episode one, Ilana and Abbi seek to make a little extra cash to see rapper Lil' Wayne, and enterprisingly attempt to busk in a park. However, in the competitive world of New York City busking, they are outshone by a talented dancer who uses their drumming rhythms to perform to the delight of onlookers, who reward the dancer but not Abbi and Ilana. They then respond to a Craig's List ad to clean a man's apartment in their underwear, Abbi with considerable reluctance. Having performed their part of the bargain, the client, played by comedian Fred Armisen, pretends he has no money to pay them, because, as he explains in baby talk, he is a "baby". In response, Abbi and Ilana destroy the meticulous tidiness of his home, upending tables, and knocking over carefully arranged knickknacks. At this point, the client's pants drop, and he is revealed to be wearing a nappy. Abbi and Ilana burst into uncontrollable laughter, steal some alcohol, and the episode ends with the two friends sitting outside on a neighbourhood stoop, in the cold New York winter's night, drinking together merrily.

This absurd romp through the exploitations, humiliations, and joys of attempting to make a living in New York offers audiences a comedic yet critical take on how middle class young women, that is, those who have been encouraged to see themselves on a particular trajectory towards career "success", are negotiating a "post-girlpower" cultural context (Harris and Dobson 2015) of precarity, insecure employment and lowly paid work (Adkins 2016). We suggest Broad City's portrayal of the difficulties of survival in such conditions grapples with shifts in gendered social relations and labour markets, as part of a suite of recent US television that moves from workplace and home-based sitcoms to 
centre young women's experiences, and their lived and felt economic and social insecurities (deCarvalho 2013). We focus on Broad City as a feminist intervention into otherwise prevalent cultural narratives that reinvigorate highly gendered and unequal expectations in the context of economic downturn, and call on women to act as savvy investor-entrepreneurs across domestic and public spaces (McRobbie, 2016; Negra and Tasker, 2014). Key to our argument is the alternative configuration of the relation between femininity, labour and thrift in the show. Broad City centres the high energy striving that is required of young women in order to make do with few material resources. However, it valorises this thrifty striving, showing its psychic and emotional sustenance of the women's friendship, which spills across the public spaces of the city, rather than directing such energies towards purely domestic "home-making" and the accrual of capital and private property.

We explore how Broad City represents instances of young women's "affective dissonance" (Hemmings 2012) with gendered discourses and feeling rules of post-Fordist configurations of labour. Drawing on a feminist framework privileging affect as a site of social orientation, in this article, we attempt to articulate how the kind of high-energy striving that is required to survive "thriftily" in such conditions is tied to contemporary youthful femininity. Such affective striving, on the one hand, may be seen as part of the "passionate work" that re-embeds youthful femininity within the promises of capitalist flourishing. Yet, importantly, Abbi and Ilana's characters embody this kind of normatively feminine high energy striving, we suggest, while also critically foregrounding the social and material conditions in which this affective gendered subjectivity has emerged. Abbi, and particularly Ilana often strive aimlessly or unsuccessfully, fail at their endeavours, work very hard for little, or unpredictable material return (waitressing tips, selling their art, and busking). At the same time, they direct excessive amounts of energy into each other, investing in their friendship over both work and other kinds of relations. This affective striving, then, is not confined in its direction to the self or the domestic home space; nor is it directed towards the neoliberal investment in intimate others as future labouring subjects. Abbi and Ilana's collective energy is articulated as necessary for their day to day affective survival, generated from moment to moment across the streetscapes of the city, public transport, park benches, and on neighbourhood stoops. Thus, in Broad City's acknowledgement of the high energy striving required under recessional conditions, the show critically questions the relation of such striving to idealised gendered economic subjectivities and the promise of career and financial success. Instead, the show emphasises the necessity of such striving in relation to the bonds of women's friendship in conditions of material and social hardship, and inevitable "failures" (Halberstam, 2011) suggesting new understandings of what "home" might entail. 
Femininity, high-energy striving and thrift in post-recessional media culture In the wake of the 2008 global financial crisis ("GFC"), feminist media scholars have noted certain shifts in the representations of women in Western media culture. In the early 2000s, Negra and Tasker (2014) note that media culture addressed to women audiences showed significant ties to the bubble culture of the first decade of the twenty-first century. Across US film and television, young women were featured as affluent, self-fashioning consumers who were negotiating an abundance of "choices" in lifestyle, career and leisure. Post-recession, such representations of consumption and women's spending power have been uneasily negotiated and "downsized" (p. 14), with figures such as the "recessionista" and "frugalista" (Nathanson 2014) emerging. Writing on fashion bloggers' championing of savvy spending, Nathanson (2014: 144) observes that conditions of austerity do not necessarily limit, but rather, reconfigure gendered patterns of consumption as "young women are encouraged to define themselves through working within economic restraints that encourage heightened attention to creative approaches to consumer culture", often modelling the collapse of distinctions between consumption and production. As taste cultures emerge in the cultural "space between postfeminist discourses and economic exigency" (Nathanson 2014: 137), women continue to be charged with the roles of responsibly determining appropriate household and personal consumption, while increasingly modelling such prudent yet desirable consumption-production through media. We witness the rise of feminine micro-enterprise in the visibility of "mommy bloggers" who recommend lifestyle "hacks" and shortcuts, attempting to capitalise on the performance of domestic work (Taylor 2016), as well as fashion, beauty and lifestyle bloggers who demonstrate their entrepreneurial value in the performance of everyday life (Duffy \& Hund 2015). Such movements are also exemplified in the rise of the digital craft economy on sites such as Etsy, in which the (perfect) home becomes a central signifier of value in the production of high-labour, low volume creative goods (Luckman 2016). The home and the so-called private sphere, then, must be capitalised upon in order to succeed in competitive economic conditions, intensifying the demands of women for continuous labour as well as a future-oriented, prudent, investor orientation in all aspects of life.

Women have long been "flexible" workers, blurring the boundaries between reproductive and productive work (Adkins 2016). As such, post-GFC media culture does not abandon but reconfigures gendered labour practices, aligning new norms with economic subjectivities deemed suitable for adapting to worsening and more competitive conditions. In view of the increasing de-collectivisation of everyday life, the retreatist representation of thrift or responsible consumption on "investment" pieces of homeware and fashion, and pleasure in domestic labour has become salient across film (Thoma 2014), financial reporting, and news 
media (Negra \& Tasker 2014), reality and makeover television (Hamad 2014), the online craft economy (Luckman 2016) and influencer culture (Nathanson 2014). As such, we suggest the mediated representation of thrift may both encompass a reflection of new financial exigencies that women are expected to bear, as well as the normative gendering of the labour that is expected to soften the impacts of financial crisis. Such representation signals not simply a shift in economic conditions but the increasing burden, and indeed, high energy striving, that women are required to take on in "making do" in a context where distinctions between personal and home life and professional life are collapsed in favour of the demonstration of value in all spheres of life (Gregg 2011).

Entangled in this injunction to strive in all spheres of life is the increasingly salient formulation of "passionate work" whereby labour is conflated with self-fulfilment. Angela McRobbie describes it as follows:

... a distinctive mode of gender-retraditionalization (as defined by Adkins) whereby the conservatism of post-feminism re-instates young women's aspirations for success within designated zones of activity such as creative labour markets, which then becomes spaces for the deployment of highly normative femininity such as 'girlish enthusiasm', which can be construed as a willingness to work all hours for very little pay in the hope of gaining a foothold in the field of work (Adkins 2002). (McRobbie 2016: 110)

In McRobbie's (2016) argument, the language of the "dream job", often found in glamorous portrayals of the creative industries, is now part of the commonsense vocabulary for young women across social axes like class and racialisation. In these circumstances, the demonstration of pleasure in work becomes a vital marker of normative femininity; not demonstrating such pleasure becomes a clear mark "of personal failure or of being the wrong person for the job" (McRobbie 2016: 103).

We observe that McRobbie (2016) poses a critique of the way these neoliberal feeling rules (Kanai 2019) of "girlish enthusiasm" attach young women to an impossible trajectory within neoliberal capitalism. We take up this focus on the affective regulation of subjectivity to highlight the ways in which media culture generates attachments to the "good life" in recessionary culture. Indeed, there is a strong mutuality between the production of "positive" feelings like resilience, confidence and optimism and the affective investment young women are encouraged to make in precarious conditions of labour (Banet-Weiser 2018, Gill and Orgad 2015), leaving little space for dissatisfaction or critique (Kanai 2019). The gendered affective regulation attached to passionate work may be seen as a corollary to increasingly commonsense discourses of human capital, whereby 
individual character and attitudinal traits such as flexibility, thrift, perseverance and future orientation are explained as the solution for achieving social mobility, employability and self-determination in capitalist economies that structurally produce unequal outcomes (Kafer 2013, Taylor 2018).

Yet, we suggest that it is also possible to imagine an alignment of such gendered enthusiasm and passion that is oriented primarily towards important social and collective bonds, and away from capitalist re-attachments. We suggest that such possibilities are seen in the recent growth of women-produced media culture where many young women themselves, both within and outside of the creative industries, are engaging critically with notions of the kind of high-energy feminine striving mandated in these conditions, and the failed promises of neoliberal higher education and passionate work, even for white middle class women. Media culture that engages with these post-girlpower conditions includes the proliferation of post-recessional television in the US featuring young, urban women negotiating economic duress such as 2 Broke Girls, New Girl, Girls, and television that centres the professional and personal dissatisfactions and anxieties of young women like Crazy Ex-Girlfriend, Insecure, Jane the Virgin, and The Mindy Project. Lauren deCarvalho (2013) suggests that the spate of programming featuring a focus on young women's economic insecurity may in fact re-intensify masculine authority in the wake of the expression of lack of ambition and drive by young women, suggesting this is in relation to the popular TV show Girls. However, we suggest that there are also productive cultural shifts here, in which upbeat, can-do and self-confident affects associated with neoliberal girlpower myths are critically examined and sometimes overtly eschewed. Such television may offer some important cultural spaces for the expression of young women's "affective dissonances", resentment, critique, and anger with both the material conditions and feeling rules of neoliberalism (Dobson \& Kanai 2018, Negra \& Tasker 2014).

Following Clare Hemmings (2012) we suggested the importance of highlighting such cultural representations in the process of a broader feminist cultural "affective divestment" in gendered neoliberal success narratives (Dobson \& Kanai 2018) and mythologies of "the good life" (Berlant 2008, 2011), through an analysis of the affective politics of contemporary media culture as a site for the collective symbolic investment in particular ways of life. For Hemmings, a feminist politics necessarily begins with a dissonance that is felt with the current social arrangements: effectively, "[I]n order to know differently we have to feel differently" (2012: 150). It is this affective dissonance that provides the grounds for politicisation, Hemmings suggests, orientating the self towards social transformation. Our analysis of affect and feelings rules in post-GFC television created by and centred on young women attempts to chart the complexities and 
contradictions of the psychic life of neoliberalism (Scharff 2015), where young women's anger and insecurities appear to be finding more cultural footings, amongst strong ongoing cultural drives towards gendered notions of confidence, perfection, resilience, shamelessness, and invulnerability (McRobbie 2015, Kanai 2019; Gill \& Kanai 2018). In our analysis of some of the key themes across the series, we suggest Broad City as contributing to this critique through the orientation of such high energy striving not towards capitalist re-attachments but feminist solidarity.

Our analysis of the series over the arc of its five seasons from 2014-2019 is concerned with contemporary feminine subjectivity and feminist politics. In our research on US post-recessional television created by and centred on young women, we mobilise Hemmings' notions of "affective dissonance" as a framework to help us identify and analyse the prominence of negative affects in recent post-recessional TV created by young women. We have analysed recent US television created by and centre on young women in terms of expressions of anger, insecurity, anxiety, and dissatisfaction in their lived experiences, particularly in relation to working life (Dobson and Kanai 2018). Here we build on this previous analysis to consider notions of feminine subjectivity as related to the activities of "thriftiness" and "home-making" in Broad City. Again thinking through the frame of "affective dissonance", we firstly overview the story of the friendship of the two protagonists, and then go on to draw attention to specific stories across the seasons in Broad City that deal with themes of thrift and home-making, specifically portraying disaffection with the kinds of linear trajectories and privatised, individualised technologies of self mandated in recessional culture, but also evince a feminist hope in the power of social bonds.

\section{Broken Post-Fordist Promises and the Foundations of Friendship}

Released in 2014 on Comedy Central, Broad City, like Girls, 2 Broke Girls and other US post-recession programming focused on young women, is premised on negotiating financial exigency without the guarantee of a promising future. Over its five seasons, neither Abbi nor Ilana are on track to an "upwardly mobile" trajectory of fulfilling, creative work. While having attended the prestigious NYU in their early adulthood, most likely at considerable cost, Abbi's "dream" career pathsthat of artist and/or gym trainer-will likely not pay off that investment. Beyond this long term goal in the romantic pursuit of autonomy and self-expression, Abbi simply cannot find enough work and a market for her art to materially sustain herself. Accordingly, Abbi's job during the first two seasons of the show is to work as a cleaner at the gym. The frequent requests for Abbi to clean up vomit, pubic hair and other bodily traces are foregrounded as "drudge work" and indeed, Abbi's 
job represents one of the most casualised, and devalued occupations at the gym (and in wider Western society). It is this gap between Abbi's position and her desires that effectively questions the kinds of affective fantasies that are presented to young women as achievable and doable in the wake of increasing manifestations of social inequality. Abbi's desired occupations reference the luminous idealised "top girls" (McRobbie 2009) of the post-Fordist contract: either the upwardly mobile young woman who autonomously builds a career in the creative industries (McRobbie 2016); or the young woman who literally demonstrates her value through investment in her body through exercise and wellness (Harjunen 2017). The disjuncture between Abbi's reality and dreams is clear; she herself does not fit the "top girl" specifications. In her physical exercise, she is too aggressive and competitive; in her artistic pursuits she is not sufficiently confident.

Ilana, by way of contrast, has fewer aspirations. At Ilana's job at sales company Deals! Deals! Deals!, it is made evident that Ilana invests no effort and takes no responsibility in her job, much to the frustration of her fellow workers. Via this framework, Broad City takes aim at the necessary link between labour and reward. Later in the series, after Ilana is fired, she finds work at fancy fusion restaurant Sushi Mambeaux (S4, Ep 2 "Twaining Day"). The restaurant at first mandates that Ilana undermine the diners and be "mean" in order to maintain the cool prestige of the restaurant and effectively upsell menu items. Rather than force herself to play this role, Ilana instead decides to "be herself", and, through her natural effervescence and charm, she finds herself richly rewarded, cashing in 800 dollars on her first shift. Ilana is suddenly "rich" at a moment by just being "who she is" when Abbi, who is represented as the more diligent, hardworking and responsible, is penniless.

In contrast to dominant state-based representations of thrift in recessional culture and its connection to idealised forms of economic subjectivity (Bull \& Allen 2018), the enforced thrift of the show is severed from any necessary connection to personality or self-management on the part of the two protagonists. Rather, it is used as means of showing how, despite the odds, they persevere in thriving while subsisting in the larger setting of New York City and its dynamics, difficulties, and odd and funny people. As noted above, while the two women are NYU graduates and thus command a certain level of cultural capital, this cultural capital has failed to convert into economic capital. This disconnection is effected, notably, during most of Season 4, where Ilana is temporarily flush with cash. (Notably, it is this literal cash under her bed that is later responsible for a bedbug infestation (S4, Ep 9 "Bedbugs"). Ilana does not know what to do with her money; for herself, she spends $\$ 480$ on getting her nails done. She lavishes her money on Abbi in the form of an extremely expensive handbag, at a time when Abbi is destitute and has spent two hours recycling empty bottles to make four dollars. Abbi is touched 
by this present and treats it as a talisman, waltzing into the upmarket lifestyle store Anthropologie and seemingly effortlessly finding a job there, in a story arc parodying rom-com conventions. However, such good luck is short lived; she is then mugged at gunpoint, her handbag stolen, together with the remaining \$374 to her name. The glamorous sales position she thought she was being offered turns out to be one as a security guard for the store.

In short, Abbi and Ilana can only rely on their genuine affection and support for each other. The fundamental place of their friendship as the foundation for the show is foregrounded in the episode "Sliding Doors" (S4, Ep1), which features as the origin story of the pair's friendship. Riffing off the 1999 film of the same name, the episode positions two alternative storylines beginning from the deciding moment in 2011 where the Abbi and Ilana, strangers at this point, miss or manage to catch their train. In the alternate universe where Abbi and Ilana miss the train due to a guy vomiting on the train platform, Abbi and Ilana meet and become friends straightaway in what is positioned as a "Good Day in New York City". In contrast, in the universe where Abbi and Ilana manage to catch their train, they have an awkward encounter, sit on opposite ends of the carriage and proceed on their separate ways in a "Bad Day in New York City". In the Bad Day, Ilana awkwardly tries to join a group of Black dancers on the train, accidentally gets kicked in the teeth, and inadvertently insults them by presuming they are poor when they are also students at NYU in the prestigious Tisch performing arts school.

Abbi similarly struggles in the Bad Day: she is harassed by a street seller of water guns, and attacked by the serial pest, the "New York Snipper", who cuts off her ponytail. Ilana is bullied on the basis of her Jewish appearance by the mean white girls she lives with in a NYU flat. Contrastingly, in the Good Day, Abbi, telling Ilana that she is also Jewish, gives Ilana the confidence to wear her hair curly when she has been straightening her hair to hide her Jewishness. Ilana fires up at the water gun street seller when he harasses Abbi. This Good Day, the episode later reveals, is fantasy. After discussing the thrill of Barack Obama's election as president and the certainty that a woman president will follow, at the end of the Good Day storyline, both Abbi and Ilana get run over by a bus featuring a prominent advertisement for Donald Trump's reality show, The Apprentice. The Bad Day, we see, is actually the Real Day; Abbi and Ilana meet on a park bench, dejected after their respective horrible days. They smoke weed, eat pizza, and thus the friendship begins more modestly; a friendship based on sustaining each other through the degrading, embarrassing, and fatiguing everyday experiences that New York City often presents.

This origin story positions the friendship as an essential affective resource that significantly differs from the "girlfriendships" associated with consumption, 
luxury and aspiration that Alison Winch (2013) has documented in both makeover television and sitcoms such as Cashmere Jungle, Lipstick Jungle and of course, Sex and the City. It is this emotional glue that secures the sense of belonging and "ontological security" (Giddens 1991) required for the two women to continue thriving in this dynamic but also difficult city. The show re-orients the high energy striving that is usually directed towards the domestic home and intimate others as objects for the investment of reproductive labour in hetero-patriarchy, towards this refreshingly aspiration-less but emotionally crucial friendship. In this relationship, Abbi and Ilana take turns in routinely egging each other on to do things they ordinarily would not be able to do, embarrass themselves in the pursuit of helping out each other's sexual prospects, impersonate each other to fill rostered shifts in hostile and strictly-run food coops, act as nurse when the other is ill, and rescue each other when high on prescription medication in the store Wholefoods. Thus, while the two friends have fun together, their amusing experiences often constitute the elaborate and energetic gymnastics required to get by in competitive urban centres of capital, and recover from the constant series of mishaps and uncomfortable experiences encountered in this environment.

\section{Finding Comfort, Security and Sustenance Across Public and Domestic Spaces}

In Broad City, public spaces feature as the "home" that drives much of the narrative and amplifies and expands the scope of Abbi and Ilana's friendship; it is this urban New York landscape of park benches, subways, food coops, remote postal delivery depots, boutiques, neighbourhood bodegas, and public basketball courts that Abbi and Ilana inhabit. We have noted above that the "home" has long featured as a site through which women's work is channelled into the labour underpinning capitalist endeavour and the necessary sustenance of labouring bodies. Broad City allows the high-energy striving of Abbi and Ilana's friendship to exceed the confines of the home and the capitalisation of intimate and domestic spaces, by allowing this affective energy to develop and move across domestic and public spaces. Broad City notably celebrates public life in New York City, much like Sex and the City some time ago, a show that also crucially extended feminine intimacies and friendships from the domestic sphere to the city's cosmopolitan culture (Nash and Grant 2015). However, due to Abbi and Ilana's material financial limits, Broad City differs in that New York City is not primarily depicted as a site of glamorous consumption. It is also not foregrounded as a site of tourism: contrasting experiences of the city are set up neatly in Season 1 (S1, Ep 6, "Stolen Phone"), where a tourist mistakenly takes Abbi's phone and the two must track its progress around Times Square, the Statue of Liberty, and other busy tourist 
destinations. Rather, New York City features as a playground for the friends' escapades which often are to do with the possibilities of fun these women can creatively generate together within their clear financial limits, and the strength of their friendship in sustaining each other despite the odds.

One of the crucial linchpins that frames Broad City from the outset is the mutual relation between the desire to thrive in New York City, and the reality of subsistence in one of the most expensive cities in the world to live in. The episode "BnB-NYC" (S3, Ep7) foregrounds the situation where the nightlife of New York City is positioned as the women's "home" for the night. Abbi and Ilana thriftily rent out their apartments using a website platform similar to the Airbnb accommodation platform. Although their apartments are not the glossy kind usually featured in Airbnb highlights, they are quickly snatched up given the real estate stranglehold. But because the two mistakenly time their postings, their BnB bookings mean they have nowhere to stay. They attempt to camp on the roof of Ilana's building, but their tent is blown off their heads in a huge gust of wind. They are momentarily homeless. The two then go clubbing, crashing a fancy birthday party where they pretend to know the host. Following what seems like flirtatious texting, Abbi returns to her apartment hoping to hook up with her BnB guest, only to find that her BnB guest has stolen all her belongings. There are repeated portrayals throughout the seasons of this show of "crashing" in New York Citythat is, squatting, making do, trying to rub the edges off the city's sharp surfaces, stoops, benches, corners, and doorways. As such, Abbi's and Ilana's affective bonds, and the labour that they invest in such bonds, are presented as crucial to making a comfortable home out of this city.

Notably, the home lives of Abbi and Ilana do not correspond to the idealised forms of domesticity that mark contemporary lifestyle trends for women. In keeping with the show's overall portrayal of the home space as an unglamorous, uncomfortable, and sometimes a literally infested site, in Season 4, Ilana confronts the nightmare of bedbugs in her apartment (S4, Ep 9, "Bedbugs"). Ilana's own mother, brother, and boyfriend treat her as a plague carrier when she needs to stay elsewhere during the bedbug treatment and will not let her into their homes. And yet, despite the general fear of contagion that bedbugs pose, Abbi readily accepts Ilana in her apartment, after taking the necessary and ingenious precautions of wrapping her in several layers of plastic bags, while Ilana consoles Abbi over her abovementioned mugging. The scenes that take place in their domestic spaces reinforce the notion of the friendship itself as the key comfort of "home", via scenes of the two women hanging out together in their apartments in slightly physically awkward or overtly uncomfortable positions and surrounds-for instance, squashed together on Ilana's bed, which takes up most of the floor space in her room, huddled around a tiny space heater in an otherwise-freezing apartment, 
in the episode discussed below (S4, Ep 6, "Witches"), and wrapped in plastic to prevent the spread of Ilana's bedbugs (S4, Ep 9, "Bedbugs").

The domestic space of the shared apartment is, at best, an unpredictable source of comfort in the series-too cold or hot, too small to allow for privacy or space, and, for Abbi, unprotected from her flatmate's slob boyfriend Bevers, who is frequently in the apartment space in various states of undress. Such domestic uneasiness is juxtaposed with Abbi's clearly foregrounded desires for domestic comfort. As a fan of the store Bed, Bath and Beyond, and the upmarket women's clothing and lifestyle brand Anthropologie, Abbi's desires for the affirming comforts of luxurious domestic lifestyle products such as candles, bedsheets, and a space heater that Drew Barrymore recommends (mentioned throughout season 4) are hardly ever met. Featured as the more conventional friend in contrast to whacky and irrepressible Ilana, Abbi's desires might be understood in terms of the attachments to normalcy and convention that Lauren Berlant $(2008,2011)$ has articulated in her discussion of women's intimate publics and cruel optimism. Yet, we suggest Abbi's desire for certain high-end domestic and lifestyle-oriented brands, products, and objects are foregrounded not necessarily to affirm Abbi's entrapment through consumption, but to showcase a legitimate desire for stability and security, that women must continually work to furnish for themselves.

The domestic scenes and plotlines around living arrangements in the show across the seasons often reinforce the financial instability of these two young women and the emotional, material, and logistical problems that arise as a result of living in New York City on a tight budget. The plot of the episode "Florida" (S4, Ep 7) dramatises this situation. In this episode, Abbi and Ilana travel to Florida with Ilana's mother and brother. While Ilana's mother cleans out her late grandmother's retirement village condo in preparation for its sale, the two friends stumble on an open-house inspection in the complex. They are awed by the spaciousness of the apartment, with Abbi commenting in amazement that "the kitchen is its own room." When the estate agent overhears them he nods and smiles, "It's a home." Abbi replies, knowingly, "Ah, a home. We don't have those. We have New York City apartments." When the two friends find out the cheap monthly rent they immediately decide to apply for tenancy, despite not meeting the usual age requirements for doing so. Envisaging a life of significantly greater domestic comfort, and financial and logistical ease in the warm climate and leisure-oriented lifestyle of Florida, the two work themselves into a state of frenzied excitement about a dream life together in Florida. They immediately put in behind-the-scenes work in order to increase their chances of finding a new Florida home. They befriend the elderly residents and persuade them to vote for their application at the upcoming board meeting by involving themselves in the leisure pursuits of the retiree residents. They referee ladies' tennis matches, offer free gun polishing, and 
flirt with elderly men in wheelchairs. While they ultimately decide to return to their freezing New York apartments due to the racist dynamics of the retirement village. The episode thus foregrounds the tension between the protagonists' desires for the material comfort and security envisaged in these more legitimised and legible "homes, and the question of what "comfort" might mean politically, of what kinds of "homes" might be liveable and for whom.

The episode "Witches" (S4, Ep 6) both works with and expands desires for comfort beyond the domestic sphere, beginning with Abbi and Ilana freezing together in Abbi's apartment because the heating in the building is broken. Their conversation revolves around Abbi's desire to purchase a space heater recommended by Drew Barrymore when she saves enough money. With the reference to Barrymore's recommendation (a running gag across the series), the heater symbolises both a physical comfort that is just beyond Abbi's financial reach, as well as the kind of cool, comfortable and effortless domestic lifestyle epitomised by Barrymore as a Gen-X celebrity. Her desire for the space heater drives Abbi to take to the streets entrepreneurially to sell a stack of greeting cards she once made. She sets up a table at a local market and is gifted some soup and a scarf to protect her "wing area" by a friendly older woman also selling craft in the market. Abbi notes that she is "actually warmer out here" than she was inside her apartment, reiterating a central theme of the series that the domestic is not necessarily a space of shelter and comfort. However, this friendly encounter unsettles Abbi: she is discomfited by her affinity with the older white woman, both in terms of her aging feminine appearance and her status as an old and still visibly struggling artist.

Beyond acknowledging the desire for domestic security, this episode also grapples with the entangled bodily, career, and financial insecurities women negotiate in relation to the impossible time/body demands of the contemporary sexual contract. Meeting such a contract notably requires the capacity to freeze time so that regardless of age, women appear "youthful" and "girlish" in keeping with the understanding of the body as an "asset" (Negra 2008), while also achieving career and financial success early on in youth in order to effectively participate in the world as consumer-citizens (McRobbie 2009). Following her dread of ageing in poverty catalysed by meeting her co-seller, Abbi meets a fresh-faced dermatologist at her stall, an Asian woman who is 51 but miraculously looks even younger than Abbi who, as Abbi defensively notes, is "still in her 20s". Abbi consequently makes an appointment to get Botox injections with the small amount of cash she has made. However, questioning her motives for doing so, Abbi halts the injection process halfway through, and by the end of the episode, comes to live with her aging self. With Ilana, she serendipitously encounters a gathering of self-proclaimed "witches" in a local city park at night-time. The group includes Abbi's older craft seller, as well as Ilana's elderly Black female sex therapist, 
who plays the role of a magical healer from a concurrent plot in the episode. Abbi runs off to convince the other "miracle worker", the dermatologist, to join in the celebration too, and the group of noticeably racially and generationally diverse female "witches" come together chanting and dancing around a bonfire. Significant here is the location of this event, outside in a public park at, on a cold New York City winter's night. The women's "magic" is channelled not into individualised healing but into this collective public ritual of togetherness, which the show playfully depicts as cracking the façade of a Trump skyscraper. The culmination of the episode highlights thrifty fun, literal warmth, and support as available via the occupation of the city's public spaces in the affective ties of the community of women who come together here.

\section{Affective Dissonances and Re-investments}

In advanced capitalist economies, McRobbie (2016) asserts that young women have a crucial symbolic role to play because of the ways in which ideas of meritocracy, youthful femininity, affective striving and creative self-fulfilment are knitted together to obscure the material inequalities of conditions of labour. While work appears to be increasingly varied and "flexible" in its movement outside of traditional sites such as the factory and the home, labour and notions of self-fulfilment are condensed in such a way as to disarticulate the possibility of structural critique, positioning any kind of dissatisfaction as a problem of the self. We have suggested that Broad City directly grapples with such hollow promises while taking seriously the affective striving that young women perform in their everyday lives. Whilst such post-Fordist labour conditions require an affective investment in capitalism, we have argued that Broad City acknowledges the normative, gendered nature of such high-energy striving but orients such affective energies towards women's friendship and a hope in the power of collective social bonds. In doing this, notions of home-making are materially expanded from the private and the domestic, to a broader view of solidarity and social and affective sustenance.

Importantly, through an enlarged view of home-making and through the centring of women's friendship in the series, Broad City provides new ways of thinking through the necessity of care in a context in which women's work is continuingly trivialised, and only valued when converted into capital. As feminist scholars such as Sylvia Federici (2013, Federici 2012) have established, capitalism produces a durable and ongoing crisis in the work of care, the burden of which is

overwhelmingly borne by women. Yet, refusing care work as socially necessary labour risks "destroying ourselves and the people we care for" (Federici 2013). Here, through Broad City, we have questioned what it means to challenge such 


\section{Culture Unbound}

Journal of Current Cultural Research

movements in post-Fordist capitalism through attention to both the affective dissonances and requisite girlish enthusiasm and high energy striving required to imagine alternative configurations of support and sociality. It is this attention to the necessity of the investment of energy in strengthening social relations and bonds that we have focused on in this article, as a means of surviving the harsh material realities of recessional culture.

Dr Akane Kanai is a lecturer in the School of Media, Film and Journalism at Monash University. Her research on femininity, race, sociality and the politics of affect in media has been published in outlets including Feminist Media Studies, the Journal of Communication, and Cultural Studies. Her book, Gender and relatability in digital culture, is published by Palgrave Macmillan. Email: akane. kanai@monash.edu

Dr Amy Shields Dobson is a Lecturer in Internet Studies at Curtin University. Her work focuses on youth, gender politics, social media, and feminine subjectivities. She is the author of Postfeminist Digital Cultures (2015), and editor of Digital Intimate Publics and Social Media (2018) with Brady Robards \& Nicholas Carah, both published by Palgrave. Her recent projects include research into cyber-safety and sexting education, female genital cosmetic surgery, and girls' and young women's social media cultures.

\section{References}

Adkins, Lisa (2016): "Contingent Labour and the Rewriting of the Sexual Contract," Lisa Adkins \& Maryanne Dever (eds): The Post-Fordist Sexual Contract: Working and Living in Contingency, Basingstoke: Palgrave Macmillan, 1-28.

Banet-Weiser, Sarah (2018): Empowered: Popular Feminism and Popular Misogyny, Durham, NC: Duke University Press.

Berlant, Lauren (2008): The female complaint: the unfinished business of sentimentality in American culture, Durham, NC: Duke University Press.

Berlant, Lauren (2011): Cruel Optimism, Durham, NC: Duke University Pres.

Broad City, S1, Ep 1, "What a Wonderful World," Comedy Central, January 22, 2014.

Broad City, S1, Ep 6, "Stolen Phone," Comedy Central, Feburary 26, 2014.

Broad City, S3, Ep 7, "BnB NYC", Comedy Central, March 30, 2016.

Broad City, S4, Ep 6, "Witches", Comedy Central, October 25, 2017.

Broad City, S4, Ep 7, "Florida", Comedy Central, November 8, 2017.

Broad City, S4, Ep 9, "Bedbugs", Comedy Central, November 29, 2017.

Bull, Anna, \& Kim Allen (2018): "Introduction: Sociological Interrogations of the Turn to Character," Sociological Research Online, 23:2, 392-398. doi: $10.1177 / 1360780418769672$.

DeCarvalho, Lauren J (2013): "Hannah and Her Entitled Sisters: (Post)feminism, (post)recession, and Girls," Feminist Media Studies, 13:2, 367-370. doi: 10.1080/14680777.2013.771889.

Dobson, Amy Shields \& Akane Kanai (2018): "From 'can-do' girls to insecure and angry: affective dissonances in young women's post-recessional media," Feminist 


\section{Culture Unbound}

Journal of Current Cultural Research

Media Studies, 19:6, 771-786.

Duffy, Brooke \& Emily Hund (2015): '"'Having itAll" on Social Media: Entrepreneurial Femininity and Self-Branding Among Fashion Bloggers," Social Media + Society, 1:2, 41-58. doi: 10.1177/2056305115604337.

Federici, Silvia (2012): Revolution at Point Zero: Housework, Reproduction, and Feminist Struggle, PM Press: Oakland, CA.

Federici, Silvia \& Maria Vischmidt (2013): "Permanent Reproductive Crisis: An Interview with Silvia Federici", Mute, March 7 2013: http://www.metamute.org/ editorial/articles/permanent-reproductive-crisis-interview-silvia-federici (accessed November 1, 2018).

Giddens, Anthony (1991): Modernity and Self-Identity: Self and Society in the Late Modern Age, Cambridge: Polity Press.

Gill, Rosalind \& Kanai, A. (2018) "Mediating Neoliberal Capitalism: affect, subjectivity and inequality." Journal of Communication. 68:2, 318-326. doi: 10.1093/joc/jqy002

Gill, Rosalind, \& Shani Orgad (2015): "The Confidence Cult(ure)," Australian Feminist Studies 30:86, 324-344. doi: 10.1080/08164649.2016.1148001.

Hamad, Hannah (2014). "Fairy Jobmother to the Rescue: Postfeminism and the Recessionary Cultures of Reality TV.” Diane Negra \& Yvonne Tasker, Gendering the recession: Media and culture in an age of austerity, Durham, NC: Duke University Press, 223- 245.

Harris, Anita, \& Amy Shields Dobson (2015): "Theorizing agency in post-girlpower times." Continuum 292, 145-456. doi.org/10.1080/10304312.2015.1022955

Harjunen, Hannele (2017): Neoliberal Bodies and the Gendered Fat Body, New York: Routledge.

Hemmings, Clare (2012): “Affective Solidarity: Feminist Reflexivity and Political Transformation," Feminist Theory 13:2, 147-161. doi: 10.1177/1464700112442643.

Kanai, A (2019). "On not taking the self seriously: Resilience, relatability and humour in young women's Tumblr blogs.” European Journal of Cultural Studies, 22:1, 60-77. doi: 10.1177/1367549417722092

Luckman, Susan (2016): "Micro-enterprise as Work-Life 'Magical Solution'," Lisa Adkins \& Maryanne Dever (eds), The Post-Fordist Sexual Contract: Working and Living in Contingency, Basingstoke: Palgrave Macmillan, 91-108.

McRobbie, Angela (2009): The Aftermath of Feminism: Gender, Culture and Social Change, London: Sage.

McRobbie, Angela (2015): "Notes on the Perfect." Australian Feminist Studies 30: 83: 3-20. doi: 10.1080/08164649.2015.1011485.

McRobbie, Angela (2016): Be Creative: Making a Living in the New Culture Industries, Cambridge: Polity Press.

Nash, Meredith, \& Ruby Grant (2015): “Twenty-Something Girls v. Thirty-Something Sex And The City Women." Feminist Media Studies 15:6, 976-991. doi: 10.1080/14680777.2015.1050596.

Negra, Diane (2008): What a girl wants? Fantasising the reclamation of self in postfeminism. London: Routledge.

Nathanson, Elizabeth (2014): "Dressed for Distress: Blogging and the 'New' Pleasures of Fashion." Diane Negra \& Yvonne Tasker, Gendering the recession: Media and culture in an age of austerity, Durham, NC: Duke University Press, 136-160.

Negra, Diane, \& Yvonne Tasker (2014): "Introduction. Gender and Recessionary Culture." Diane Negra \& Yvonne Tasker, Gendering the recession: Media and culture in an age of austerity, Durham, NC: Duke University Press, 1-30.

Scharff, Christina (2015): "The psychic life of neoliberalism: Mapping the contours of

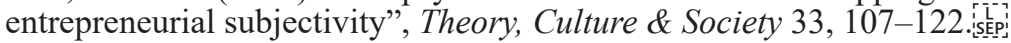

Taylor, Jessica (2016): "Laptops and playpens: 'Mommy Bloggers' and Visions of Household Work." Lisa Adkins \& Maryanne Dever (eds), The Post-Fordist Sexual 
Contract: Working and Living in Contingency, Basingstoke: Palgrave Macmillan, 109-128.

Thoma, Pamela (2014): "What Julia Knew: Domestic Labor in the Recession-era Chick Flick". Diane Negra \& Yvonne Tasker, Gendering the recession: Media and culture in an age of austerity, Durham, NC: Duke University Press, 107-135.

Winch, Alison (2013): Girlfriends and Postfeminist Sisterhood, Basingstoke: Palgrave Macmillan. 